\title{
The Influence of E-Service Quality and Relational Marketing on E-Satisfaction in Using Mobile Banking through User Experience at Bank Syariah Mandiri Medan Petisah Branch Office
}

\author{
Cindy Ayu Putri', Paham Ginting ${ }^{2}$ \\ ${ }^{1}$ Postgraduate Students Department of Management, Faculty of Economics and Business at University of \\ Sumatera Utara, Indonesia \\ ${ }^{2}$ Postgraduate Lecturer Department of Management, Faculty of Economics and Business at University of \\ Sumatera Utara, Indonesia \\ Corresponding Author: Cindy Ayu Putri
}

\begin{abstract}
Sharia banking is a banking system developed according to the Islamic sharia Bank Syariah Mandiri as a sharia bank in Indonesia which applies this system among conventional banks which appear in large numbers. The objective of the research is to analyze the influence e-service quality and relational marketing on esatisfaction in using mobile banking through user experience. The research uses quantitative research method associative approach which aims to find out the correlation between two or more variables. The data is gathered by using structured questionnaires with 5 points of interval scale. The population is 1.475 clients who use mobile banking of Mandiri Syariah Mobile and 315 of them are taken as the samples by using Slovin formula and simple random sampling technique. The gathered data are analyzed by using statistic method with SEM Smart PLS. The result of the research shows that e-service quality and relational marketing has a positive but insignificant influence on e-satisfaction. User experience has a positive and significant influence on esatisfaction. E-service quality and relational marketing has a positive and significant influence on user experience. E-service quality and relational marketing has a positive and significant influence on e-satisfaction through user experience.
\end{abstract}

Keywords: E-service quality, Relational marketing, E-satisfaction, User experience

\section{INTRODUCTION}

Sharia bank is a financial services company which is being developed that still require improvement in order to improve the quality of service for its customers. To improve the ability to compete against conventional banks, then the sharia banks should prioritize the quality of the services in accordance with the tastes of the customer and professional service, so that customer satisfaction is met. The level of competition that the higher resulted in sharia banks should still exist and are capable of competing against conventional banks (Wiwoho, 2014).

At the time this was going on the transformation of banking. How the best bank in the world to respond to these changes and how the principles of the main competitors to force us to think about banking in a different way. One of them is a transaction with a smartphone have exceeded the transaction branch, but the bank is still centered on the branch in both the organization and design (King, 2020).

With the increasing number of banks that apply the principles of sharia, both sharia banks or sharia business units, there is a big challenge for them for providing a 
service that is best and offers the experience for the customer to meet the emotional needs of the customer. Based on the phenomenon that marketers should start thinking to give a feeling of comfort and security to its customers. So, will the customer will be satisfied with the experience that marketers give and so the customer can decide which banks are selected to be trusted to manage its finances (Nofinawati, 2015).

Association of Sharia Banks in Indonesia (Asbisindo) stated that sharia banking in Indonesia has the momentum to grow but it should be able to get through the challenges of banking that become the focus of sharia banks in the running of the work. It is characterized by statistical data from the Financial Services Authority, which recorded a total of sharia banking assets as of January $2020 \mathrm{Rp}>10$ Billion. Asset growth shows that sharia banking is experiencing a growth of 23,28 percent year on year (Asbisindo.or.id)

In the context of online, conceptualized e-satisfaction as an assessment of consumers on the internet experience they are compared with their experience with traditional ways in the face of the customer (Magdalena and Jaolis, 2018). Similarly, in the research journal Amin (2016) to explain e-satisfaction as the satisfaction of the customer in connection with the purchase experience or previous use with the company selling products or services. In this study, the satisfaction will be seen as a construction separate from the quality of the service and will be restricted to the definition of the assessment of the specific transaction (Amin et al., 2015). In this perspective, Alikhan and Zubair (2019) explained that the diversity of products, the physical form, responsiveness, interaction and stability significantly influence customer satisfaction of internet. Dipa et al., (2020) emphasize that most of the customers of mobile banking were satisfied with the accessibility of the internet, the ease of use, usefulness and trust. As a result, the perception of consumers that the positive (or negative) about the quality on various attributes of electronic services will produce satisfaction (or dissatisfaction) with the electronic services provided through the website (Arcand et al., 2017).

E-service quality, or also known as e-servqual is a new version of the service quality (Servqual). E-servqual was developed to evaluate a service provided on the internet network. E-service quality is defined as a tool or instrument to get the size of the level of satisfaction of customers of an internet based service consists of the expenditure and the delivery of products or services (Budiman et al., 2020). The measurement is done by comparing between the expectations of the services that are expected with the services received by the customer. Service a service or product quality, will certainly have an impact on satisfaction for its user. With the rapid growth and use of internet extensively in the marketing practices of companies, the delivery of quality services through the electronic platform for electronic trading to be one of the issues most critical for marketers in the service sector (Zavareh et al., 2012).

In addition to the e-service quality, relational marketing considered the effect on e-satisfaction, there is generally a relational conduct analysis as well as improvements in the relationships that are familial with the public or parties outside the company who have an interest and a big hand in the company, including the community (Raharjo, 2013). One of the strategies that can be applied to create satisfaction is to establish an ongoing relationship between the bank and the customer, where this strategy is known by the term relational marketing (Kotler and Amstorng, 2016). Relational marketing in terms of mobile banking is to emphasize the recruitment and maintenance our customers through the company relationship with its customers. In a study conducted by Katsikeas (2019) stated that relational marketing is key to the success of banking on the future now. Interest in relational 
marketing continue to grow stronger as evidenced by the flow of scientific work is ongoing.

With some banks may see an inconsistent shape design for various products, such as checking versus the loan. Banks should strive to groove app easily and without friction a consistent look and feel and branded (Extractable.com Best Digital Experience in Banking, 2019). Because the components contained in the important relational marketing, namely communication, commitment and trust then supported also with attractive features.

This study adds to the user experience as an intervening variable, the user experience is the findings of a new technology in the digital era that strongly supports economic activity in this case will be discussed banking activities. The modernization of the digital requires banks to reinvent their core business in lending, retail banking and payments. This will replace both the branches with digital channels cheaper which allows the bank to build economies of scale with the capital investment is much lower (Mbama et al., 2018).

Service to be a differentiation at once determinant of the success or failure of banking in keeping the customers that already exist and attract prospective new customers. One of the services provided banking in the era of the time mobile banking. The emergence of mobile banking as one of the innovations that further simplify the banking activity because it eliminates the boundaries of space and time (Komulainen and Saraniemi, 2018).

The transformation of banking is about new capabilities, new jobs, and skills that ensure the competence that never required the bank to the present. Banks in the era of 4.0 is about the ability of fintech startup to create a transformative experience that is faster and cheaper than can be done by the bank of the incumbent anywhere. So that the banks should increase the satisfaction of its customers through the quality of services of electronic, relational marketing and also the user experience so that customers remain on the bank (King, 2020).

Through its mobile phone and mobile banking, transaction banking which is usually done manually, meaning that activities previously carried out by the customer to come to the bank, can now be done without having to visit the outlets of the bank only by using the customer's mobile phone can save time and cost, in addition to saving time mobile banking is also intended that the customer is not outdated in using electronic media that is modern and can also better utilize the mobile media that is usually used to communicate but also can be used for business or trade (Hapsara, 2015).

$$
\text { Mobile banking provides }
$$

convenience to the customers to do banking transactions such as check balances, transfer between accounts and others. With this facility all the people that have a mobile phone can easily trade anywhere and anytime. In the end the bank rollicking facilities mobile banking for the sake of gaining satisfaction and the increase in the number of customers. With the application can also open his own account without waiting in line and service of customer complaints has been available 24 hours in the app named AISYAH (Assistant Interactive Mandiri Syariah) so that it can submit a complaint directly contact in chatbot (www.bsmnet.syariahmandiri.co.id).

\section{LITERATURE REVIEW E-Satisfaction}

E-satisfaction as a consumer ratings over the internet experience they are compared with their experiences with traditional ways in the face of the customer. Can be explained e-satisfaction as the satisfaction of the customer in connection with the purchase experience or previous use with the company's products and services (Amin, 2016). 


\section{E-Service Quality}

E-service quality is the services provided on the network of the internet as an extension of the ability of a site to facilitate the activities of shopping, purchasing, distribution effectively and efficiently (Chase, et al., 2006).

\section{Relational Marketing}

Relational marketing shows the relationship between the company and the customer elected woke up in a long-term relationship that is mutually beneficial. According to Buttle (2015) stated that relational marketing is the core business strategy that combines the manufacturer and the function of internal, external networks to create and deliver value to the customers to earn a profit.

\section{User Experience}

User Experience is the perception of and response to a person resulting from the use and or anticipated use of a product, system or call. More simple, the User experience is how a person's feelings towards any interaction that you are faced with what is in front of you when you use it (Winter and Thomaschewski, 2015).

\section{KERANGKA KONSEPTUAL}

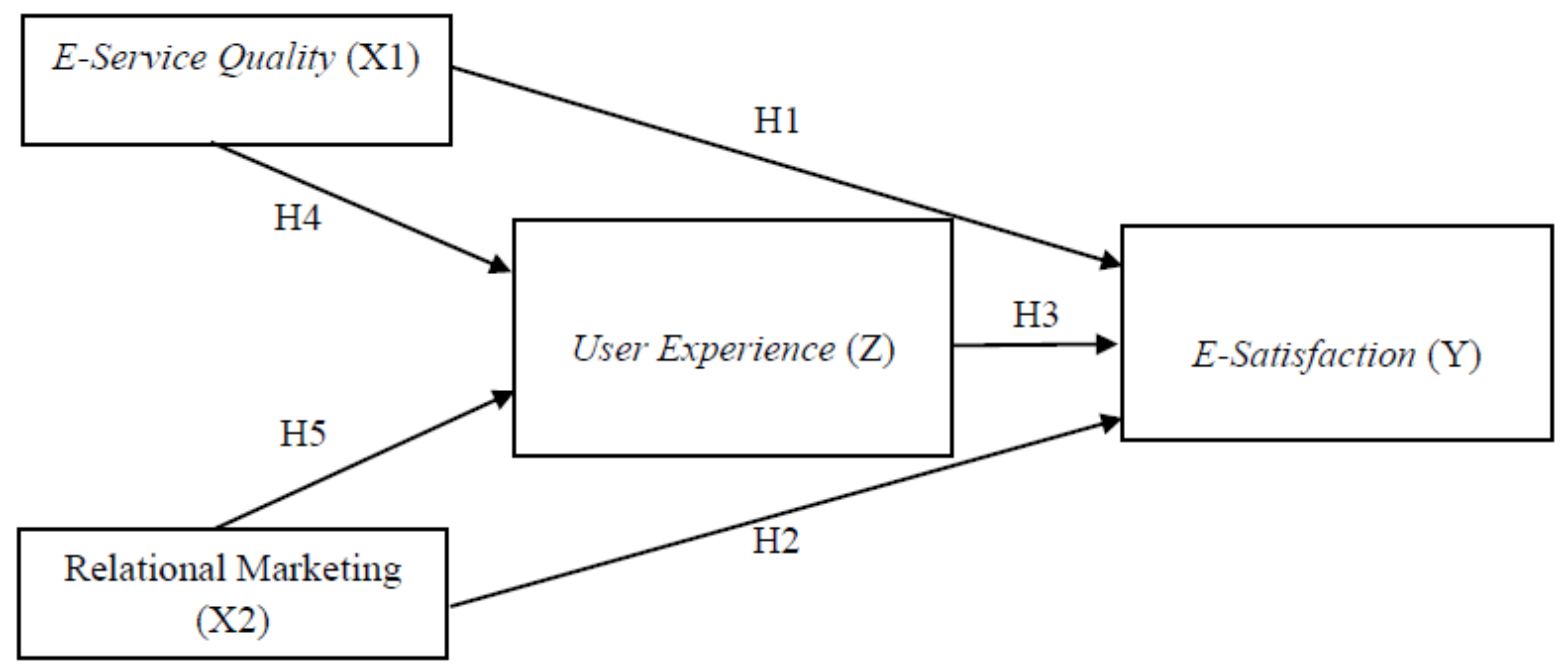

Figure 1. Conceptual Framework

\section{Hypothesis}

Based on the background research and the relationship between variables, then the research hypothesis:

1. E-service quality has a positive and significant influence on e-satisfaction in using mobile banking at Bank Syariah Mandiri KCP Medan Petisah.

2. Relational marketing has a positive and significant influence on e-satisfaction in using mobile banking at Bank Syariah Mandiri KCP Medan Petisah.

3. User experience has a positive and significant influence on e-satisfaction in using mobile banking at Bank Syariah Mandiri KCP Medan Petisah.
4. E-service quality has a positive and significant influence on user experience in using mobile banking at Bank Syariah Mandiri KCP Medan Petisah.

5. Relational marketing has a positive and significant influence on user experience in using mobile banking at Bank Syariah Mandiri KCP Medan Petisah.

6. E-service quality has a positive and significant influence on e-satisfaction in using mobile banking through the user experience at Bank Syariah Mandiri KCP Medan Petisah.

7. Relational marketing has a positive and significant influence on e-satisfaction in using mobile banking through the user 
experience at Bank Syariah Mandiri KCP Medan Petisah.

\section{MATERIAL AND METHODS}

This research type is associative research. According to Sugiyono (2017) understanding of associative is research that aims to determine the relationship of two or more variables. With this study the authors wanted to see how e-service quality, relational marketing and user experience of e-satisfaction on the customer Bank Syariah Mandiri Medan Petisah.

The population in this study is as much as 1.475 people the customer to use mobile banking Bank Syariah Mandiri. The technique of sampling in this research is using the technique of sampling by the method of nonprobability sampling Maholtra et al., (2017). Types of non probability sampling technique used is simple random sampling. Simple random sampling according to Maholtra et al., (2017) is the retrieval of the sample members of the population that was randomly without regard to strata that exist in the population.

Data collection was conducted by Questionnaire, Interview and Documentation. This study uses a Likert Scale as a research tool.

\section{RESULTS AND DISCUSSION}

E-service quality has a positive and insignificant influence on e-satisfaction in using mobile banking at Bank Syariah Mandiri KCP Medan Petisah.

Based on the path coefficient it shows that e-service quality has a positive and insignificant influence on e-satisfaction of customers at Bank Syariah Mandiri KCP Medan petisah. This means that Hypothesis 1 is rejected which means that e-service quality is considered not very capable of increasing customers e-satisfaction with mobile banking Bank Syariah Mandiri. Seen from the test results directly where the value of significance 0.147 more of 0.05 . The customer not getting the satisfaction that they desire such as visual display application Mandiri Syariah Mobile, handling of constraints and application access. This may be caused because the customer compare with other banks that have their respective advantages on the app online banking. According to research by Kim (2010) mention that satisfaction of internet users in the United states and South Korea, influenced by the variables of eservice quality which consists of the dimensions of privacy, efficiency, system availability and fulfillment, the direction is also positive and significant. Charles (2016) provide confirmation that the relationship between e-service quality on satisfaction and loyalty of users of e-banking in general in Nigeria have the direction that a positive and significant. In this study found that eservice quality has insignificant influence on e-satisfaction, this is in line with research conducted by Aziati (2020) get that eservice quality has insignificant influence on e-satisfaction for shopee e-commerce mobile application users.

Relational marketing has a positive and insignificant influence on e-satisfaction in using mobile banking at Bank Syariah Mandiri KCP Medan Petisah.

Based on the path coefficient it shows that relational marketing has a positive and insignificant influence on esatisfaction of customers at Bank Syariah Mandiri KCP Medan petisah. This means that Hypothesis 2 is rejected which means that relational marketing is considered not very capable of increasing customer esatisfaction with mobile banking Bank Syariah Mandiri. Seen from the test results directly where the value of significance 0.103 greater than 0.05 . This is due to the presence of some of the tickets from the application according to users not in accordance with the needs of day to day and the user application is not fully faithful to the banking products and marketing provided by Bank Syariah Mandiri because of the use of and payment by the customer through the application of other banks. In line with that, e-commerce and the internet 
have given rise to new opportunities to create and maintain customer relationships and facilitate relationship management in the banking sector (Garrett et al., 2014). But the reality in the field there are still customers who have not felt fully the relational marketing in the purchase through the banking application, still feel to come to the office more efficient and trust with the information provided from the office directly even there are customers who feel more easily and quickly went to the office to do the needs of the transaction. This research is in line with research conducted by Sarandang et al., (2014) stated that relational marketing has insignificant influence on customer satisfaction in using product of Noodles Steven.

User experience has a positive and significant influence on e-satisfaction in using mobile banking at Bank Syariah Mandiri KCP Medan Petisah.

Based on the path coefficient it shows that user experience has a positive and significant influence on e-satisfaction of customers at Bank Syariah Mandiri KCP Medan petisah. This means that Hypothesis 3 is accepted which means that user experience is considered capable of increasing customer e-satisfaction with mobile banking Bank Syariah Mandiri. Seen from the test results directly where the value of significance of 0.001 is smaller than 0.05 . This is because many of the customers agree to answer are already fulfilled his needs in his experience using mobile banking Bank Syariah Mandiri. From all the respondents answers can be said that the experience of the customer in using the application Mandiri Syariah Mobile affect their satisfaction. Although not on any existing indicators, Mandiri Syariah Mobile is still give a memorable experience to customers that generate satisfaction on the use of the application Mandiri Syariah Mobile. This is in line with research Suandana (2016) found that the experience of buying fashion products online has positive influence and significant impact on customer satisfaction.
Research conducted Yulianti (2017) that to get that user experience has positive and significant influence on e-satisfaction on the user mobile operators in Indonesia. Another study conducted by Dewi et al., (2018) who find that the user experience has positive and significant influence on customer satisfaction in using application PayTren in Jabodetabek. Intanny et al., (2018) that user experience influence e-satisfaction on the use of Jogyaplaza.id.

E-service quality has a positive and significant influence on user experience in using mobile banking at Bank Syariah Mandiri KCP Medan Petisah.

Based on the path coefficient it shows that e-service quality has a positive and significant influence on user experience of customers at Bank Syariah Mandiri KCP Medan petisah. This means that Hypothesis 4 is accepted which means that e-service quality is considered capable of increasing the user experience with mobile banking Bank Syariah Mandiri. Seen from the test results directly where the value of significance is 0.000 is smaller than 0.05 . This is because the dominant answers from the customer agrees of the whole question, however still there are also some customers who still feel the slow pace of accessing mobile banking and the slow resolution of problems experienced by the customer. Of course this is of concern to the Bank Syariah Mandiri to continuously improve the service quality and the service of digital. This is in line with research Sutanto (2020) that eservice quality has positive significant impact on user experience. The services provided by the Bank Syariah Mandiri give effect to the experience of the use of the mobile banking application. The experience obtained based on existing indicators on eservice quality better experience in getting the ease in accessing the application Mandiri Syariah Mobile, experience in the use of the features of banking in the application as well as experience handling technical constraints on the use of the application. 
Relational marketing has a positive and significant influence on user experience at Bank Syariah Mandiri KCP Medan Petisah.

Based on the path coefficient it shows that relational marketing has a positive and significant influence on user experience of customers at Bank Syariah Mandiri KCP Medan petisah. It means that Hypothesis 5 is accepted that relational marketing is considered capable of increasing the user experience with mobile banking Bank Syariah Mandiri. Seen from the test results directly where the value of significance is 0.000 is smaller than 0.05 . This is because the answers of the customer answered agree and strongly agree of the whole question, the customer already feel fulfilled with the use of digital products provided by Bank Syariah Mandiri through the marketing to the customer. However Bank Syariah Mandiri should remain and further strengthen the relationship marketing with customers so that customers remain confident with marketing given and increase the satisfaction of his experience in using Mandiri Syariah Mobile. Research done Widjaja (2016) has the result that shows that relational marketing has a positive effect significantly to the user experience. The use of Mandiri Syariah Mobile user customers to conduct all banking activities. Promotional products of Bank Mandiri Syariah easily accessible and a quick response when you want to get more information about the product. This provides a good experience for customer which is one of the good achievement for the Bank Syariah Mandiri.

E-service quality has a positive and significant influence on e-satisfaction in using mobile banking through the user experience at Bank Syariah Mandiri KCP Medan Petisah.

Based on the path coefficient it shows that e-service quality has a positive and significant influence on e-satisfaction through user experience of customers at Bank Syariah Mandiri KCP Medan Petisah.
This means that Hypothesis 6 is accepted that means user experience is an intervening variable that can bridge the gap between eservice quality with e-satisfaction. E-service quality is considered capable of increasing customer e-satisfaction through the user experience with mobile banking Bank Syariah Mandiri. Seen from the test results of the indirect where the significance value of 0.003 smaller than 0.05 . This is due to the overall e-service quality provided by the Bank Syariah Mandiri provides a good experience for its customers. Services such as time efficiency, features, privacy is maintained, visualization applications and also the responsibility of the Bank Syariah Mandiri cultivate the experience of use in terms of range, personalization and trust. Customer satisfaction is achieved because of Bank Syariah Mandiri strives to provide quality service and best experience for the customer. This research is in line with the research of Zhao and Zhang (2019) show that the influence of system quality and service quality on user satisfaction is stronger for experienced users higher than experienced users and low positive significant to experience a high. Komulainen and Saraniemi (2018) concluded that the experience obtained from the use of mobile banking in banking have a relationship to each other in creating satisfaction to banking customers. It is also in line with research conducted by Komulainen and Saraniemi (2018) which shows that the interaction between services and users, namely the process of customer experience as experienced by users, creates value for users.

Relational marketing has a positive and significant influence on e-satisfaction in using mobile banking through the user experience at Bank Syariah Mandiri KCP Medan Petisah.

Based on the path coefficient it shows that relational marketing has a positive and significant influence on esatisfaction through user experience to customers at Bank Syariah Mandiri KCP 
Medan Petisah. This means that Hypothesis 7 is accepted that means user experience is an intervening variable that can bridge the gap between relational marketing with esatisfaction. Relational marketing is considered capable of increasing customer e-satisfaction through the user experience with mobile banking Bank Syariah Mandiri. Seen from the test results do not directly where the value of significance 0.002 smaller than 0.05 . This is because the overall relational marketing provided by Bank Mandiri Syariah provides a good experience for its customers. It can be seen that the simplicity of the application is very helpful for customers in using the application Mandiri Syariah Mobile, then the provision of information on banking products with very coordination delivered to the customer as well as the experience that is needed the customer that the efficiency of the time. This research is in line with research Sheth (2017) that relational marketing should involve understanding more holistically about the customer to collect, analyze, and interpret the conversation in addition to a stream of thought that is not realized or realized. Finally, Payne and Frow (2017) suggest that the role of relational marketing should include all stakeholders as this is a concept that will make the interdependence of relational marketing more relevant and explicit.

\section{CONCLUSIONS AND RECOMMENDATIONS CONCLUSIONS}

Based on the results of research and discussion in the previous chapter, it can be concluded as follows:

1. E-service quality has a positive and insignificant influence on e-satisfaction in using mobile banking in Bank Syariah Mandiri Branch Office Medan Petisah.

2. Relational marketing has a positive and insignificant influence on e-satisfaction in using mobile banking in Bank Syariah Mandiri Branch Office Medan Petisah.
3. User experience has a positive and significant influence on e-satisfaction in using mobile banking in Bank Syariah Mandiri Branch Office Medan Petisah.

4. E-service quality has a positive and significant influence on the user experience in using mobile banking in Bank Syariah Mandiri Branch Office Medan Petisah.

5. Relational marketing has a positive and significant influence on the user experience in using mobile banking in Bank Syariah Mandiri Branch Office Medan Petisah.

6. E-service quality has a positive and significant influence on e-satisfaction in using mobile banking through the user experience in Bank Syariah Mandiri Branch Office Medan Petisah.

7. Relationship marketing has a positive and significant influence on esatisfaction in using mobile banking through the user experience at Bank Syariah Mandiri Branch Office Medan Petisah.

\section{RECOMMENDATIONS}

\section{For The Company}

a) Bank Syariah Mandiri should always do updates to features and the visualization of the application to avoid delays in the application system that ultimately does not make an error when used.

b) Bank Syariah Mandiri banking product information must be submitted and packaged in an attractive appearance so that customers are interested in finding out and joining and always up to date and always innovative so as not to be left behind from other Islamic banks.

c) Bank Syariah Mandiri should always pay attention to the feedback and complaints from customers as an increase in the future.

\section{For Further Research}

It is recommended in future studies can examine the other variables in Bank Syariah Mandiri outside variables in this study. 
Acknowledgement: None

\section{Conflict of Interest: None}

\section{Source of Funding: None}

\section{REFERENCES}

1. AliKhan, Mukaram and Syed SohaibZubair. 2019. An Assessment of E-Service Quality, E-Satisfaction and E-Loyalty, Case of Online hopping in Pakistan. South Asian Journal of Business Studies Vol. 8 No. 3, 2019 pp. 283-302.

2. Amin, et al. 2015. Pengaruh Kualitas Pelayanan Terhadap Kepuasan Pelanggan dan Dampkanya Pada Loyalitas Pelanggan. Jurnal Administrasi Bisnis, Vol.17 No 1 Desember 2015.

3. Amin, Muslim. 2016. Internet Banking Service Quality and its Implication on Customer Satisfaction and E-Customer Loyalty. International Journal of Bank Marketing Vol. 34 No. 3, 2016 pp. 280-306.

4. Arcand, Manon., Sandrine P, Isabelle B. and Lova R. 2017. Mobile Banking E- Service Quality and Customer Relationship. International Journal of Bank Marketing. Vol.35 No.7.

5. Aziati, Yusrina. 2020. Analisis Pengaruh User Experience Terhadap Kepuasan Pengguna Mobile Application e Commerce Shopee Menggunakan Model Delone \& Mclean.

6. Budiman, Arief, Edy Yulianto, Muhammad Saifi. 2020. Pengaruh E-Service Quality Terhadap E-Satisfaction Dan E- Loyalty Nasabah Pengguna Mandiri Online. Jurnal Profit Volume. 14 No. 12020.

7. Buttle, Francis and Maklan, Stan. 2015. Customer Relationship Management: Concept and Technologies. Third Edition Published 2015 by Routledge 2 Park Square, Milton Park, Abigdon, Oxon OX14 4RN.

8. Charles, K. (2016). E-banking users behaviour: e-service quality. International Journal of Bank Marketing Vol.14.

9. Chase, B. Richards, Jacobs, Robert F, Aquilano. Nicholas J. (2006). Operations Management (for Competitive Advantage)11th edition. MC. Graw Hill Companies. Singapore.

10. Dewi, Rizki., SintaSiregar, Edward H. 2018. Analisis User Experience Terhadap
Kepuasan Konsumen pada Penggunaan Aplikasi PAyTren di Jabodetabek. Library IPB.

11. DipaMulia, Hardius, Novia. 2020. The Role of Customer Intimacy in Increasing Islamic Bank Customer Loyalty in Using E-Banking and M-Banking. Journal of Islamic Marketing Emerald Publishing Limited 1759-0833.

12. Extractable.com Best Digital Experience in Banking, 2019.

13. Garrett, J. L., Rodermund, R., Anderson, N., Berkowitz, S., \& Robb, C. A. (2014). Adoption of Mobile Payment Technology by Consumers. Family and Consumer Sciences Research Journal.

14. Hapsara, Radityo Febri. 2015. Pengaruh Kegunaan, Kemudahan, Resiko dan Kepercayaan Terhadap Penggunaan Mobile Banking. Fakultas Ekonomi dan Bisnis Universitas Muhammadiyah Surakarta.

15. Intanny,ViekaAprilya., Inasari Widiyastuti., Maria Dolorosa Kusuma Perdani. 2018. Measuring Usability and User Experience of The Marketplace of Jogjaplaza.id Using UEQ and USE Questionnaire. JurnalPekommas, Vol. 3 No. 2.

16. Katsikeas, Constantine. 2019. Revisiting International Marketing Strategy in a Digital era. International Marketing Review Vol. 37 No. 3, pp. 405 - 424.

17. Kim, J. H., \& Kim, C. (2010). E-service quality perceptions: A crossculturalcomparison of american and Korean consumers. Journal of Research in Interactive Marketing, 4(3), 257-275.

18. King, Brett. 2020. Bank 4.0, Perbankan dimana saja dan kapan saja, tidak perlu bank. Mahaka publishing (inprint Republika Penerbit). Jakarta: Indonesia.

19. Komulainen, Hanna and Saila Saraniemi. 2018. Customer Centricity in MobileBanking: a Customer Experience Perspective. International Journal of Bank Marketing Vol. 37 No. 5, pp. 1082-1102.

20. Kotler, Philip and Gary Amstrong. (2016). Prinsip-prinsip Pemasaran. Edisi13. Jilid1. Jakarta: Erlangga.

21. Magdalena, Agnesiadan Ferry Jaolis. 2018. Analisis Antara E-Service Quality, ESatisfaction, Dan E-Loyalty Dalam Konteks E-Commerce Blibli. Jurnal Publikasi: Program Manajemen Pemasaran, Universitas Kristen Petra.Indonesia. 
22. Malhotra, Naresh. K., D.F. Birks, and P. Wills. 2017. Marketing research: An Applied Approach. 5th ed. London: Pearson Education.

23. Mbama, Cajetan Ikechukwuet al., 2018. JRIM 12,4 Digital Banking, Customer Experience and Financial Performance: UK Bank Managers' Perceptions. Journal of Research in Interactive Marketing. Vol. 12 No. 4, 2018 pp. 432451.

24. Nofinawati. 2015. Perkembangan Perbankan Syariah Di Indonesia. JURIS Volume14, Nomor 2 (Juli-Desember 2015).

25. Raharjo, Santoso Tri. 2013. Relasi Dinamis Antara Perusahaan Dengan Masyarakat Lokal. UNPAD PRESS. ISBN: 978-6029238-49-5.

26. Sarandang, Gabriel., Agus Supandi Soegoto, Imelda Ogi. 2014. Pemasaran Relasional, Kualitas Produk, Dan Harga Terhadap kepuasan Konsumen Produk Mie Steven pada Ud. Sehati. Jurnal Emba, Vol.2 No.3 September 2014.

27. Sheth, J.N. (2017). The future evolution of relationship marketing. In Morgan, R.M., Pa-rush, J.T. and Deitz, G. (Eds), Handbook on Research in Relationship Marketing.

28. Suandana, N. P. W., Rahyuda, K., \&Yasa, N. N. K. (2016). Pengaruh Pengalaman Membeli Produk Fashion Terhadap Niat Membeli Kembali Melalui Kepuasan dan Kepercayaan Pelanggan. Jurnal Manajemen, Strategi Bisnis Dan Kewirausahaan, 10(1), 85-97.

29. Sutanto. 2020. Pengaruh E-Service Quality terhadap Customer Loyalty denganUser Experience sebagai Variabel Moderasi Pada Penggunaan Aplikasi Go-Jek Di Surabaya.

30. Widjaja. 2016. Pengaruh Pemasaran Relational Terhadap Customer Loyalty Dan
User Experience Sebagai Variabel Intervening Pada Fuboru Indonesia. ManajemenPemasaran 2016.

31. Winter D., Schrepp M., Thomaschewski J. 2015. Faktoren der User Experience systematischeÜbersichtüberproduktrelevant e UX-Qualitätsaspekte. In: Endmann A., Fischer H., Krökel M., editors. DE GRUYTER 2015.

32. Wiwoho, Jamal. 2014. Peran Lembaga Keuangan Bank Dan Lembaga Keuangan Bukan Bank Dalam Memberikan Distribusi Keadilan Bagi Masyarakat. Jurnal Masalahmasalah Hukum: MMH, Jilid 43 No. 1 Januari 2014.

33. Yulianti, Marlita. 2017. Pengaruh User Experience Terhadap Customer Satisfaction Pada Pengguna Operator Seluler Di Indonesia. Universitas Telkom, (Manajemen Bisnis Telekomunikasi \& Informatika).

34. Zavareh, Farnaz Beheshti et al., 2012. EService Quality Dimensions and Their Effects on E- Customer Satisfaction in Internet Banking Services. The 2012 International Conference on Asia Pacific Business Innovation and Technology Management.

35. Zhou, T., Li, H. and Zhang (2019), "The effect of flow experience on mobile SNS users' loyalty", Industrial Management \& Data Systems, Vol. 110.

How to cite this article: Putri CA, Ginting P. The influence of e-service quality and relational marketing on e-satisfaction in using mobile banking through user experience at Bank Syariah Mandiri Medan Petisah Branch Office. International Journal of Research and Review. 2021; 8(8): 587-596. DOI: https://doi.org/10. 52403/ijrr.20210878 